\title{
PENGARUH KURANGNYA SUPPLY GAS LEMBAM DALAM PENANGANAN MUATAN DI MT. GANDINI DENGAN METODE FISHBONE
}

\author{
Sarifuddin $^{a}$, Winarnob dan Jijin Arga Saputra ${ }^{c}$ \\ ${ }^{a}$ Dosen Program Studi Teknika PIP Semarang \\ ${ }^{\mathrm{b}}$ Dosen Program Studi Kalk PIP Semarang \\ ${ }^{\mathrm{c}}$ Taruna (NIT.49124603.T) Program Studi Teknika PIP Semarang
}

\begin{abstract}
ABSTRAK
Inert gas adalah gas atau campuran gas yang tidak mendukung cukup oksigen untuk mendukung pembakaran hidrokarbon. Di MT. Gandini, inert gas dihasilkan oleh pembakaran di dalam scrubber dan sekaligus dibersihkan dengan menggunakan air laut dengan cara dikabutkan, sehingga kotoran hasil pembakaran jatuh ke bawah dan selanjutnya dialirkan ke overboard dan gas yang bersih dialirkan menuju deck water seal, selanjutnya masuk ke tangki muatan. Faktor penyebab supply gas lembam yang masuk ke dalam tangki muatan kurang adalah rusaknya demister filter dan tersumbatnya saluran pipa instalasi dari Scrubber menuju Deck Water Seal.

Hasil dari penelitian adalah tersumbatnya saluran pipa instalasi dari Scrubber menuju Deck Water Seal diakibatkan oleh jelaga yang dihasil dari pembakaran dalam Scrubber yang menumpuk, sehingga lubang pipa semakin lama semakin mengecil yang mengakibatkan supply gas lembam ke dalam tangki terhambat. Dampak tersebut yang membuat supply gas lembam ke dalam tangki muatan kurang optimal.
\end{abstract}

\section{Kata kunci: identifikasi, inert gas supply, fishbone, MT. Gandini}

\section{PENDAHULUAN}

\section{A. Latar belakang}

Kebutuhan jasa angkutan pelayaran dari tahun ke tahun mengalami peningkatan yang sangat pesat, khususnya kapal-kapal niaga. Kapal niaga sebagai sarana transportasi air yang mempunyai peranan sangat penting dan efisien dalam pengangkutan dari satu tempat ke tempat tujuan, salah satunya adalah kapal tanker atau kapal muatan minyak yaitu kapal yang mempunyai fungsi untuk mengangkut muatan minyak mentah maupun minyak hasil olahan atau produk dalam bentuk curah melalui jalur laut atau jalur perairan dari pelabuhan muat ke pelabuhan bongkar. Berbicara tentang minyak tentu erat kaitannya dengan bahaya yang bisa terjadi sewaktu-waktu, dalam hal ini adalah gangguan keselamatan pada saat penanganan muatan di atas kapal yang berdampak pada pencemaran lingkungan.

Melihat dari konstruksinya yang khusus yaitu kapal dengan tangki-tangki berisi minyak maupun gas baik minyak mentah, bahan kimia dan minyak hasil olahan, maka dalam membangun kapal disesuaikan dengan sifat-sifat muatan yang akan dibawa oleh kapal. Terutama kapal yang mengangkut muatan minyak bumi atau dari hasil pengolahan, karena sifat dari muatan tersebut memiliki karakteristik yang mudah menyala hal ini disebabkan karena terbentuknya gas hasil penguapan yang terus-menerus. Selain itu, di dalam tangki muatan juga terjadi reaksi kimia yang mengandung toxic (racun) berbahaya bagi orang yang terkontaminasi 
dengan gas tersebut.

Berdasarkan pada praktek laut di MT. Gandini terdapat suatu permasalah terhadap sistem gas lembam yaitu pada saat pelaksanaan bongkar muat, volume gas lembam yang masuk ke dalam tangki muatan kurang, sehingga kadar oksigen dalam tangki muatan tinggi yang mengakibatkan tidak optimalnya proses bongkar muat kapal, pelaksanaan pengoperasian dan perawatan inert gas system yang seharusnya dioperasikan oleh engineer dioperasikan oleh electrictian dikarenakan kurangnya pemahaman perawatan terhadap sistem gas lembam yang mengakibatkan perawatan sistem gas lembam kurang maksimal.

Dari permasalahan dan latar belakang itulah maka peneliti ingin membahas dan mengangkat pengaruh gas lembam dalam mencegah terjadinya gangguan keselamatan pada saat kegiatan penanganan muatan dan menuangkannya ke dalam penelitian dengan judul: "Pengaruh Kurangnya Supply Gas Lembam Dalam Penanganan Muatan Di MT. Gandini Dengan Metode Fishbone"

\section{B. Perumusan masalah}

1. Faktor apa yang menyebabkan kurangnya supply gas lembam ke dalam tangki muatan?

2. Hal-hal apa saja yang dapat terjadi apabila supply gas lembam di dalam tangki kurang pada saat penanganan muatan?

3. Upaya apa saja yang harus dilakukan untuk menjaga optimalnya kinerja sistem gas lembam tersebut?

\section{Tujuan Penelitian}

Tujuan penelitian ini adalah sebagai berikut:

1. Untuk memahami dan mengerti akan pentingnya peranan sistem gas lembam dalam prosedur penanganan bongkar muat dan perawatan yang dilakukan pada komponen instalasi gas lembam.

2. Untuk mengetahui gangguan keselamatan pada saat kegiatan bongkar muat dari kegagalan fungsi Inert Gas System (IGS).

3. Untuk peningkatan keselamatan dan pencegahan terhadap bahaya gangguan keselamatan pada saat pengoperasian kapal.

\section{Manfaat Penelitian}

\section{Manfaat Teoritis}

Sebagai referensi tambahan terhadap penelitian dengan bidang tentang sistem gas lembam dan menjadi sebuah tambahan wacana bagi rekan-rekan lain yang hendak melakukan penelitian kembali di bidang yang sama.

2. Manfaat Praktis

Sebagai panduan praktis untuk memecahkan permasalahan tentang sistem gas lembam serta meningkatkan pengetahuan akan pentingnya gas lembam dan perawatan-perawatan instalasi gas lembam sehingga kecelakaan kapal dalam hal ini dapat berkurang.

\section{KAJIAN PUSTAKA}

\section{A. Tinjauan Pustaka}

Konsep kajian mengenai gas lembam yang dikutip dari buku, Pieter batti Inert Gas System \& Crude Oil Washing (1983: 15) yang menyebutkan bahwa, pertamatama sistem ini digunakan pada kapalkapal tanker di Amerika-serikat sejak tahun 1925, dengan bermacam-macam alasan sistem ini dilupakan atau ditinggalkan selama beberapa tahun. Perusahaan "Sun oil" di Philadelphia adalah yang pertama kali menggunakan sistem ini sebagai alat keselamatan pada kapal-kapal tanker mereka pada tahun 1932, karena sebelumnya telah terjadi 
ledakan besar pada salah-satu kapalnya. Sistem yang mereka ciptakan waktu itu begitu sederhana namun terbukti sangat berhasil. Kemudian British Petroleum atau B.P. Tanker menggunakan prototype ini pada dua kapal steam pengangkut Crude Oil pada tahun 1961. Kebijaksanaan ini dilanjutkan dan sejak tahun 1963 semua kapal pengangkut "Crude Oil" dilengkapi dengan sistem ini. Menyusul kemudian penggunaan sistem ini ditekankan dalam SOLAS Convention 1974 dan peraturanperaturan serta penggunaannya disempurnakan lagi dalam Konperensi Internasional di London mengenai "Tanker Safety and Pollution Prevention, atau TSPP Protocol 1978”. Untuk mengurangi resiko terjadinya suatu kebakaran dan ledakan di atas kapal tanker maka perlu ditiadakan adanya sumber api dan udara/atmosfer yang dapat terbakar yang secara bersamaan timbul di tempat yang sama dan pada waktu yang sama, sehingga tindakan kewaspadaan umum di atas kapal tanker perlu dilaksanakan dengan tujuan secara lebih ketat meniadakan salah satu dari padanya. (Badan Diklat Perhubungan, 2000: 77).

\section{B. Definisi Operasional}

Melihat akan kenyataan pentingnya peranan sistem gas lembam pada kapalkapal tanker, menjadikan sistem ini suatu sumbangan yang sangat berharga di dalam dunia pelayaran, yang mana hal ini menimbulkan rasa keingintahuan para pembacanya dan untuk mempermudah dalam mempelajarinya maka di bawah ini akan dijelaskan mengenai pengertian dari Pengaruh Kurangnya Supply Gas Lembam (Inert Gas) Dalam Penanganan Muatan dan istilah-istilah yang ada:

1. Supply (penyedia), berarti memberi pasokan gas ke dalam tangki muatan.

2. Inert gas (gas lembam), berarti gas atau campuran gas yang tidak mendukung cukup oksigen untuk mendukung pembakaran hidrokarbon.
3. Fire point (titik bakar), berarti suhu terendah dimana suatu zat atau bahan bakar cukup mengeluarkan uap dan terbakar/menyala secara terusmenerus bila diberi sumber panas.

4. Flammable, berarti mudah menyala.

5. Flash point (titik nyala), berarti suhu terendah dimana suatu cairan mengeluarkan gas yang cukup untuk membentuk suatu campuran gas yang dapat terbakar sesaat jika ada sumber penyalaan. Suhu ini diukur di laboratorium memakai alat yang standar dengan mengikuti prosedur yang sudah ditentukan.

6. Flue gas, berarti gas sisa pembakaran yang diambil dari ketel (boiler) di kamar mesin.

7. Gas freeing (pembebasan gas) berarti memasukkan udara segar ke dalam tangki dengan tujuan mengeluarkan gas-gas beracun, serta meninggalkan kadar oxygen sampai 21\% (dua puluh satu persen) dari volume.

8. Gas lembam, berarti gas atau campuran gas yang tidak cukup mengandung oxygen untuk mendukung pembakaran hydrocarbon.

9. Inerting, berarti memasukkan gas lembam ke dalam tangki dengan tujuan untuk mencapai kondisi lembam seperti didefinisikan dalam "kondisi lembam".

10. Kebakaran, berarti bahaya api yang disebabkan oleh terbentuknya proses segitiga api (bahan bakar, panas dan oxygen), yang menghasilkan suatu reaksi berantai antara ketiga unsur tersebut secara tepat dan seimbang.

11. Ledakan, berarti pembakaran yang terjadi dalam ruang tertutup, karena terjadi penambahan tekanan pada ruang tertutup maka mengakibatkan peledakan.

12. Listrik statis, berarti aliran listrik yang terjadi karena perpindahan elektron-elektron dari molekul- 
molekul yang muatannya berlainan, listrik statis ini menimbulkan bunga api yang dapat menyalakan gas yang ada disekitarnya.

13. Plant gas lembam, berarti semua perlengkapan yang dipasang khusus untuk menghasilkan gas lembam yang dingin, bersih dan bertekanan beserta alat yang mengontrol penyalurannya ke dalam sistem tangki muat.

14. Purging, berarti memasukkan gas lembam pada saat tangki dalam keadaan kosong sehingga menjadi lembam.

15. Sistem distribusi gas lembam, berarti semua pemipaan, kerangan-kerangan dan pasangan-pasangan yang berhubungan dengan distribusi gas lembam dari plant ke tangki-tangki muat, pembuangan gas ke atmosfer dan perlindungan tangki dari tekanan lebih atau vakum.

16. Sistem gas lembam, berarti plant (penghasil) gas lembam dengan sistem distribusi gas lembam beserta sarana-sarana untuk mencegah aliran balik yang mengandung gas muatan ke ruangan kamar mesin, alat ukur yang tetap maupun jinjing dan alat pengontrol (control devices).

Berdasarkan pernyataan tersebut maka jelaslah bahwa kebakaran baru bisa terjadi kalau memenuhi persyaratan dari Segi Tiga Api/Fire Triangle, dalam bahasan ini adalah:

1. Source of ignition (asal dari percikan api);

2. Fuel dalam hal ini hydrocarbon yang memenuhi persyaratan;

3. Oxygen yang cukup untuk dapat menimbulkan kebakaran.

Apabila salah satu dari ketiga unsur ini tidak ada atau tidak memenuhi persyaratan dalam jumlah atau kadarnya, maka tidak akan mengakibatkan kebakaran.

Prosedur-prosedur dalam melakukam pengoperasian dari inert gas system antara lain:

1. Langkah Persiapan:

a. Periksa keran isap dan tekan dari air laut yang berhubungan dengan pompa srubber;

b. Periksa keran isap dan tekan dari air laut yang berhubungan dengan Deck water seal;

c. Periksa keran isap dan tekan dari air laut yang berhubungan dengan pompa bahan bakar. Semua Katup (valve) dalam posisi terbuka;

d. Periksa tabung Analyzer harus dalam keadaan terisi kurang lebih $3 / 4$ bagiannya;

e. Kalibrasi oksigen content pada inert gas analiser 20,9\%;

f. Jalankan secara manual pompa Deck water seal dan pompa Scrubber dengan menekan tombol start di control panel Inert Gas, yakinkan bahwa tekanan dari pompa scrubber $4 \mathrm{Kg} / \mathrm{cm}^{2}$ dan pompa Deck water seal $3 \mathrm{Kg} / \mathrm{cm}^{2}$. Amati pada gelas duga yang terdapat pada Scrubber dan Deck water Seal untuk memastikan air laut dari Scrubber pump dan Deck water seal pump telah berjalan secara normal;

g. Setelah itu semua pompa dimatikan kembali.

2. Langkah Pengoperasian

Pada langkah pengoperasian dari inert gas system ada 2 yaitu pengoperasian secara manual dan automatic. Cara Pengoperasian secara manual sebagai berikut:

a. Tekan tombol manual start pada control panel Inert Gas;

b. Tekan tombol start untuk menjalankan pompa scrubber;

c. Tekan tombol start untuk 
menjalankan blower;

d. Tunggu 50 detik kemudian untuk penghembusan sisa gas ke luar dari ruang pembakaran (blow);

e. Tekan tombol Glow on;

f. Tunggu sekitar 30 detik hingga bahan bakar dan udara mencapai alat pembakaran;

g. Tekan tombol Inert Gas "ON"; Tunggu sekitar 4 detik untuk memberi waktu bahan bakar mencapai induk pembakaran (main burner);

h. Tekan tombol valve open jika lampu flame on telah menyala, tunggu beberapa saat kemudian;

i. Tekan tombol ignition on dan glow on secara bersamaan;

j. Buka katup oksigen analyzer mencapai angka 5 (pada tanda);

k. Yakinkan Inert Gas Sistem telah berjalan secara normal kemudian beritahukan ke Deck control bahwa Inert Gas telah siap di supply ke tanki;

1. Tekan tombol system ready.

3. Langkah-langkah pengoperasian secara Auto inert gas system:

a. Tekan tombol auto start;

Secara otomatis dan berurutan akan berlangsung proses seperti pada cara pengoperasian secara manual;

b. Tekan tombol start untuk menjalankan pompa Deck water seal secara manual;

c. Buka katup oksigen analyzer mencapai anka 5 (pada tanda);

d. Yakinkan Inert Gas Sistem telah berjalan secara normal kemudian beritahukan ke Deck control bahwa Inert Gas telah siap di supply ke tangki;

e. Tekan tombol system ready.

\section{Air Venting}

a. Tekan tombol air venting secara Auto;
Secara berurutan akan menjalankan pompa scrubber dan Auxiliary blower;

b. Jalankan Deck water seal pump;

c. Kontak ke cargo control bahwa air venting siap di supply;

d. Tekan system ready.

5. Prosedur Stop

a. Tutup katup oksigen analyzer;

b. Tekan kembali system ready;

c. Apabila Inert Gas dioperasikan secara manual maka langsung dapat menekan tombol stop;

d. Apabila Inert Gas dioperasikan secara Auto maka dengan menekan kembali tombol stop;

e. Apabila Inert Gas dijalankan secara auto atau manual terhadap Air venting juga dengan menekan tombol stop.

\section{Kerangka Pemikiran}

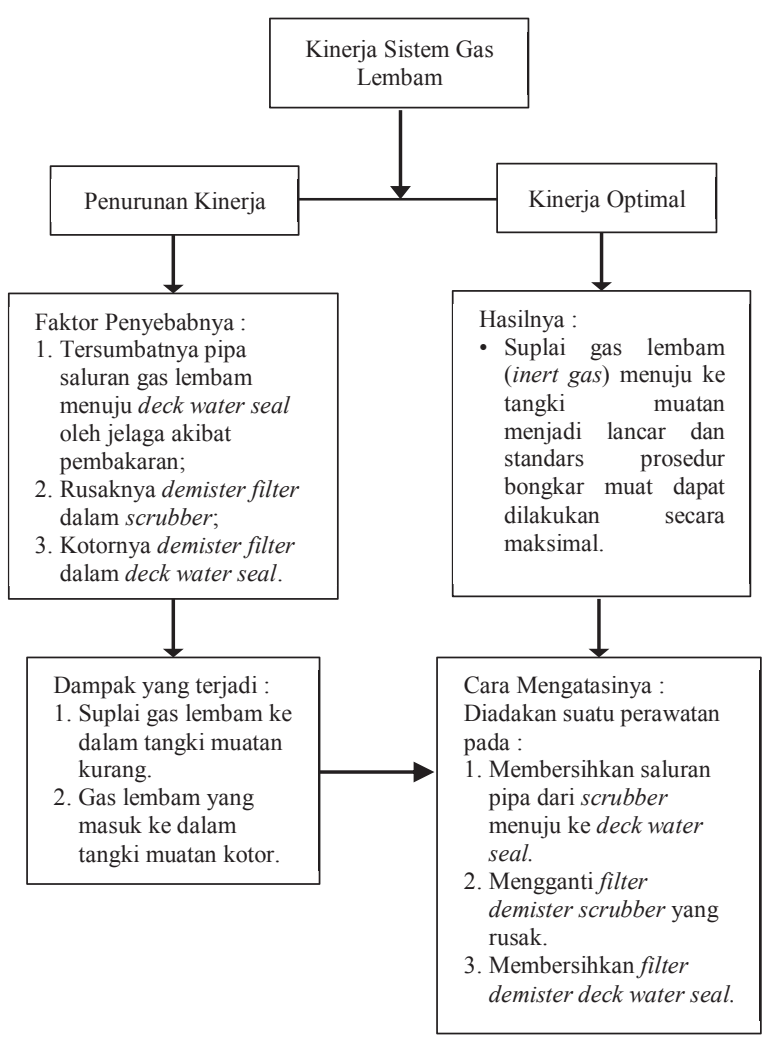


Pengaruh Kurangnya Supply Gas Lembam Dalam Penanganan Muatan Di Mt. Gandini Dengan Metode Fishbone

Sarifuddin $^{\mathrm{a}}$, Winarno ${ }^{\mathrm{b}}$ dan Jijin Arga Saputra ${ }^{\mathrm{c}}$

\section{METODE PENELITIAN}

\section{A. Waktu dan Tempat Penelitian}

Pada penulisan penelitian ini dilakukan pengkajian dengan menggunakan faktafakta dari pengalaman juga pengetahuan yang telah dipadukan dari permasalahan yang peneliti lihat dan alami saat melaksanakan praktek berlayar selama kurang lebih 12 bulan yang terhitung dari 06 Desember 2014 sampai dengan 16 Desember 2015.

Peneliti melakukan penelitian tentang sistem gas lembam ini berada di atas kapal MT. Gandini yang mana data kapal dapat dilihat di bagian lampiran particulars of machinery part.

\section{B. Pendekatan Penelitian}

Penelitian pada hakikatnya merupakan suatu usaha untuk menemukan, mengembangkan dan menguji kebenaran suatu pengetahuan dengan menggunakan metode-metode ilmiah. Para pakar mengemukakan pendapat yang berbeda dalam merumuskan batasan penelitian atau penyelidikan terhadap suatu masalah, baik sebagai usaha mencari kebenaran melalui pendekatan ilmiah.

Secara umum, penelitian diartikan sebagai suatu proses pengumpulan dan analisis data yang dilakukan secara sistematis dan logis untuk mencapai tujuan tertentu. Pengumpulan dan analisis data menggunakan metode-metode ilmiah, baik yang bersifat kuantitatif dan kualitatif, eksperimental atau non-eksperimental, interaktif atau non interaktif. Metodemetode tersebut telah dikembangkan secara intensif melalui berbagai uji coba sehingga telah memiliki prosedur yang baku.

Dalam penulisan penelitian ini, peneliti akan menggunakan metode-metode penelitian yang dapat digunakan untuk menganalisa dan membahas masalahmasalah yang ditemukan dari faktor-faktor dan data-data yang ada sehingga diperoleh kesimpulan yang diperlukan, yaitu:

\section{Fishbone Analysis}

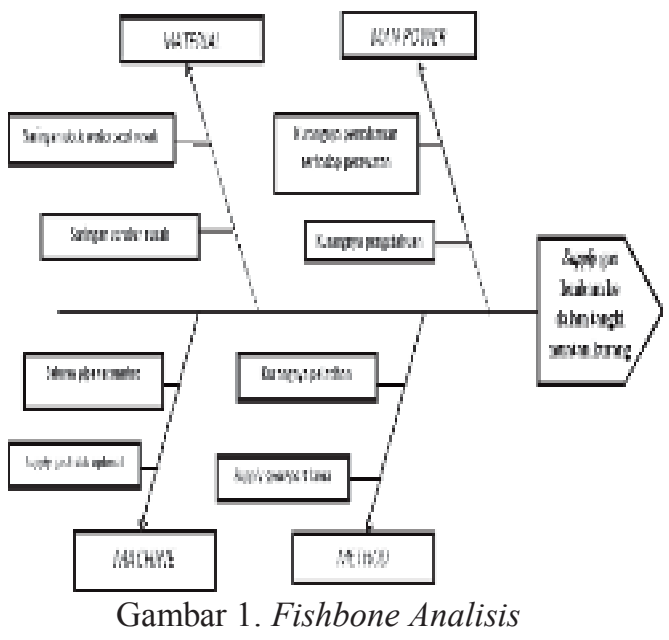

Diagram tulang ikan atau diagram fishbone adalah salah satu metode di dalam meningkatkan kualitas. Sering juga diagram ini disebut dengan diagram Sebabakibat atau cause effect diagram yang menggunakan data verbal (non-numerical) atau data kualitatif.

Fungsi dasar diagram fishbone (tulang ikan) adalah untuk mengidentifikasi dan mengorganisasi penyebabpenyebab yang mungkin timbul dari suatu efek spesifik dan kemudian memisahkan akar penyebabnya.

Pendekatan yang digunakan untuk menjabarkan metode fishbone ini adaah dengan pendekatan:
a. Man Power
b. Methode
c. Material
d. Machine 
2. Metode Deskriptif

Menurut Sugiyono metode penelitian deskriptif adalah metode penelitian yang dilakukan untuk mengetahui nilai variabel mandiri atau lebih (independent) tanpa membuat perbandingan atau menggabungkan antara variabel satu dengan yang lain.

Metode deskriptif dapat disimpulkan sebagai sebuah metode yang bertujuan untuk melukiskan atau menggambarkan keadaan lapangan secara sistematis dengan fakta-fakta interpretasi yang tepat dan data yang saling berhubungan, serta bukan hanya untuk mencari kebenaran mutlak tetapi pada hakekatnya mencari pemahaman observasi. penelitian ini selain mengandung hal-hal yang bersifat teori, juga ada hal- hal yang bersifat praktikum. Dalam pengertian bahwa selain ditulis dari beberapa literatur buku, juga bersumber dari objek-objek penelitian yang terdapat dalam buku. Penggunaan aspek visual observasi sangat berperan dalam buku ini. Oleh karena itu penelitian ini memuat tentang sebuah penelitian yang dimunculkan dalam jenis-jenis permasalahan yang akan diteliti. Dalam metode ini digunakan metode penelitian secara deskriptif. Adapun pengertian lain dari deskriptif adalah tulisan yang berisi pemaparan, uraian dan penjelasan tentang suatu objek sebagaimana adanya pada waktu tertentu dan mengambil keputusan atau kesumpulan secara umum.

\section{Metode Kualitatif}

Menurut sugiyono bahwa penelitian kualitatif adalah metode penelitian yang berlandaskan pada filsafat post positivisme, igunakan untuk meneliti pada kondisi objek yang alamih. Dimana peneliti adalah sebagai instrumen kunci, teknik pengumpulan data dilakukan secara triangulasi (gabungan) analisis data bersifat induktif / kualitatif, dan hasil penelitian lebih menekankan makna generalisasi.

Oleh karena itu didalam pembahasan nanti peneliti berusaha memaparkan hasil dari semua studi dan penelitian mengenai suatu objek yang diperoleh, baik hal-hal yang bersifat teori juga hal-hal yang bersifat praktis. Dalam artian bahwa selain ditulis dari beberapa literatur buku, juga bersumber dari objek-objek penelitian yang juga terdapat dalam buku fresh water generator. Penggunaan aspek observasi atau pengamatan sangat berperan dalam penelitian ini.

\section{Teknik Pengumpulan Data}

Teknik pengumpulan data yang digunakan dalam penulisan penelitian $\mathrm{i}$ ini didasarkan pada suatu data, fakta dan informasi yang didapat oleh peneliti pada saat melaksanakan praktek berlayar (prala) selama kurang lebih satu tahun, kemudian dari data, fakta dan informasi yang ada tersebut menjadi bahan acuan dalam penyusunan penelitian, serta didapat dari informasi yang diperoleh dari Masinis dan Kepala Kamar Mesin (KKM) dan berpedoman pada buku referensi yang kemudian menuangkannya ke dalam bentuk tulisan.

Adapun beberapa teknik pengumpulan data yang dapat dilakukan berupa:

1. Observasi

Menurut Abdurrahmat Fathoni observasi adalah teknik pengumpulan data yang dilakukan melalui suatu pengamatan, dengan disertai pencatatan-pencatatan 
Sarifuddina, Winarno ${ }^{\mathrm{b}}$ dan Jijin Arga Saputra ${ }^{\mathrm{c}}$

terhadap keadaan atau perilaku objek sasaran.

Selama peneliti melaksanakan pengamatan saat praktek berlayar, maka data-data yang tidak ada tidak dapat dilampirkan. Peneliti hanya mengalami dan mengamati langsung beberapa permasalahan yang terjadi pada sistem gas lembam di kapal tersebut yaitu masih kurangnya supply gas lembam ke dalam tangki muatan diakibatkan oleh tersumbatnya saluran gas lembam.

Dari hasil pengamatan yang ada maka peneliti merasa tertarik untuk meneliti lebih lanjut terhadap penelitian yang akan dibahas dalam penelitian ini, mengapa permasalahan tersebut dapat terjadi, kemudian mengupayakan untuk memecahkannya serta mengatasi masalah tersebut agar supply gas lembam ke dalam tangki muatan dapat tercapai maksimal.

Dalam observasi ini dilakukan pengamatan antara lain tentang:

a. Bagian-bagian utama dari sistem, fungsi dan cara kerjanya;

b. Urutan proses kerja dari system;

c. Cara pengoperasiannya;

d. Perawatan dan pemeliharaannya.

2. Dokumentasi

Dokumentasi ialah teknik pengumpulan data yang digunakan peneliti dengan gambar arsip-arsip yang ada di kamar mesin. Dan segala permasalahan yang sering di alami oleh peneliti sehubungan dengan sistem gas lembam yang kemudian peneliti dapat analisa dan mengkaitkannya dengan strategi perawatan dan perbaikan yang ada.
Teknik ini juga digunakan untuk membandingkan kinerja dari sistem gas lembam serta komponenkomponen yang menunjang pada saat keadaan normal ataupun tidak, selain itu buku-buku pendukung yang ada menjadi acuan peneliti sebagai tolak-ukur teori yang akan disajikan.

\section{Studi Pustaka}

Menurut Kartini Kartono studi pustaka bertujuan mengumpulkan data dan informasi dengan bantuan macam-macam material referensi yang berupa buku majalah, naskah, catatan-catatan, kisah sejarah dan dokumen. Dalam penelitian ini peneliti mengambil beberapa buku referensi tentang sistem gas lembam dan sistem pembakaran hal ini dimaksudkan agar buku-buku referensi tersebut dapat mendukung dan membantu peneliti dalam melakukan penyusunan penelitian ini dimana buku referensi tersebut dapat memberikan acuan-acuan teoritis dalam melakukan suatu pembahasan terhadap masalah yang diangkat meliputi penyebab kondisi tersebut serta hal-hal apa yang harus dilakukan dalam menangani masalah tersebut.

\section{Teknik Analisis}

Metode yang digunakan dalam menganalisis data yang ada dalam penelitian ini adalah metode deskriptif kualitatif fishbone, di mana dengan metode deskirptif kualitatif ini, penulis dapat menggambarkan data, membandingkan, mengkomperhensif dari permasalahan yang ditemukan ditambah data-data dari buku-buku teori, mengingat terbatasnya waktu pada saat melakukan pengamatan serta pengoperasian gas lembam yang 
terbatas.

\section{E. Metode Penarikan Kesimpulan}

Dalam penelitian ini metode penarikan kesimpulan yang digunakan adalah dengan membandingkan antara kegitan yang ada di kapal dengan pelaksanaan yang benar sesuai petunjuk yang ada dan membandingkan dengan referensi yang didapat oleh peneliti dari bidang yang sama.

\section{HASIL PENELITIAN DAN PEMBAHASAN}

A. Gambaran Umum Objek Yang Diteliti

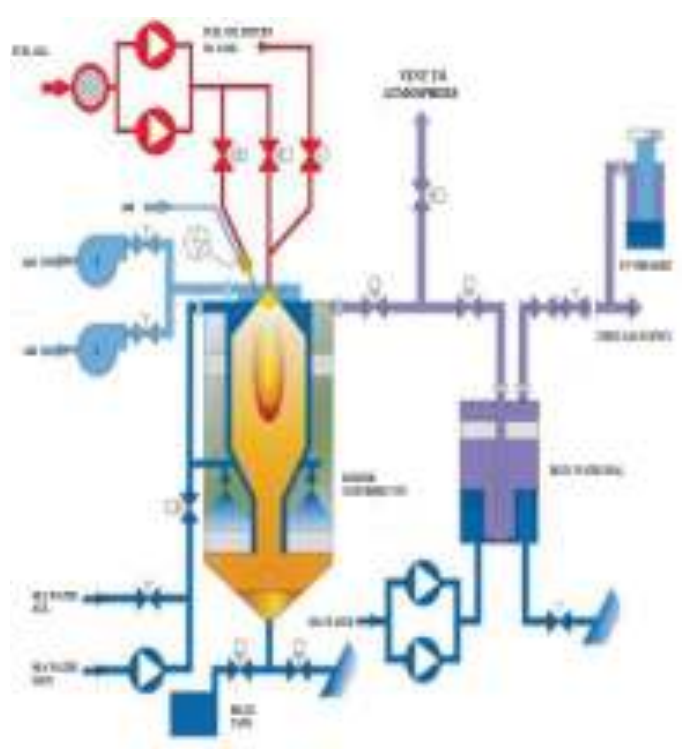

Gambar 2. Flow chart IGGS

Pada umumnya kapal tanker dibuat dan dirancang sesuai dengan kebutuhannya agar mampu membawa jenis-jenis muatan tertentu seperti product oil (minyak olahan), gas (LPG/LNG), crude oil (minyak mentah) atau chemical (bahan kimia). Selain itu juga memperhitungkan tentang aspek stabilitas, persyaratan keselamatan dan unsur pencemaran, yang mengacu pada pelayanan yang maksimal dan keamanan proses pendistribusian barang kepada pengguna jasa. Maka di dalam pengoperasiannya harus dilakukan dan diupayakan dengan baik, dalam arti bagaimana bekerja di atas kapal tanker agar dapat melakukan kegiatan dengan aman dan memperhatikan bahaya-bahaya yang dapat terjadi.

Seperti yang telah diketahui bahwa semua instalasi telah diperhitungkan dalam pembuatannya dari segi keuntungan dan kerugiannya, namun demikian sebagai alat yang bergerak maka di dalam pengoperasiannya tidak dapat dihindari adanya gangguan-gangguan, yang mana gangguan tersebut dapat disebabkan oleh berbagai kemungkinan seperti disebabkan kurangnya perawatan dan pemeliharaan yang baik, teratur, terencana dan sistematis terhadap keseluruhan kapal meliputi permesinan, konstruksi dan sistemsistem yang ada di atas kapal diantaranya ialah terhadap sistem gas lembam yang sangat berpengaruh pada keselamatan kapal tanker serta lancarnya proses bongkar muat, dimana dalam hal ini adalah mengupayakan suatu keadaan/kondisi yang sangat diperlukan yaitu tercapainya kondisi lembam untuk itu proses bongkar muat belum dapat terlaksana apabila syarat ini belum terpenuhi. Tentu saja untuk mencapai proses yang diinginkan itu bergantung dari kondisi masing-masing komponen yang menunjang kerja dari instalasi gas lembam tersebut.

Maka disini sangatlah jelas bahwa perhatian dan perawatan komponenkomponen tersebut sangatlah diperlukan mengingat saling berhubungannya komponen satu dan lainnya dan yang akan dibahas dalam hal ini ialah tentang perawatan yang dilakukan terhadap masing-masing komponen inert gas system guna terjaganya kinerja dari instalasi gas 
Sarifuddina, Winarno ${ }^{\mathrm{b}}$ dan Jijin Arga Saputra ${ }^{\mathrm{c}}$

lembam.

Dan di bawah ini adalah data-data mengenai sistem gas lembam (design specification) yang ada di atas kapal MT. Gandini adalah sebagai berikut:

- Spesifikasi : NKK

- Kapasitas : : 1.505,3 m3/h

- Kandungan oksigen : kurang dari $5 \%$

- Temperatur gas:
a. $350{ }^{\circ} \mathrm{C}$ at furnance scrubber
b. $50^{\circ} \mathrm{C}$ at inert gas main line

- Tekanan pada dek utama:

a. Max $1400 \mathrm{mmH}_{2} \mathrm{O}$

b. Min $100 \mathrm{mmH}_{2} \mathrm{O}$

- Kandungan gas pada scrubber:
a. $\mathrm{O} 2(30 \%)$
b. $\mathrm{CO} 2(13.0 \%)$
c. $\mathrm{SO} 2(0.3 \%)$
d. N2 (seimbang)

- Kandungan gas pada jalur utama:
a. $\mathrm{O} 2(3.0 \%)$
b. $\mathrm{CO} 2(13.0 \%)$
c. $\mathrm{SO}_{2}$ (kurang dari $0,03 \%$ )
d. $\mathrm{N}_{2}$ (seimbang)
e. partikel padat $<7,5 \mathrm{mg} / \mathrm{Nm}^{3}$

Masalah yang sering timbul adalah supply gas lembam yang masuk ke dalam tangki muatan kurang, maka pesawat inert gas system sebagai pesawat yang dapat memproduksi gas lembam harus dapat bekerja dengan optimal. Di bawah ini adalah tabel penjelasan dari hasil observasi.

Tabel 1. Hasil Analisis Faktor Penyebab Berdasarkan Hasil Observasi

\begin{tabular}{|c|c|}
\hline Faktor penyebab & Jumlah permasalahan \\
\hline Man & 2 \\
\hline Method & 2 \\
\hline Material & 2 \\
Machine & 2 \\
Adapun fakta yang berkaitan
\end{tabular}

sehubungan dengan permasalahan yang ada ialah pada saat bongkar muat kadar oxygen dalam tangki harus dijaga jangan sampai melebihi 8\% (delapan persen) dari volume dan dengan tekanan yang selalu positif didalam tangki.

Pada Kapal MT. Gandini. Pada saat melakukan proses bongkar-muat (cargo operation) di pelabuhan Balikpapan, terjadi gangguan dimana tiba-tiba terdengar alarm dari engine control room yang setelah diamati menunjukkan kadar/kandungan oxygen di dalam tangki melebihi batas normal yang diijinkan dan tekanan gas lembam pada tangki kurang. Kemudian setelah dilakukan pengecekan oleh Masinis jaga dan dengan melaporkan masalah tersebut kepada chief engineer atau KKM (kepala kamar mesin) dan berpedoman pada instruction manual book pada sistem tersebut ternyata terdapat kendala pada instalasi pipa gas lembam yang menuju ke tangki muatan yang mengakibatkan pasokan gas lembam ke dalam tangki muatan menjadi kurang. Sehingga proses bongkar muat tidak dapat dilaksanakan sesuai dengan standart operasional procedure.

\section{B. Analisa Masalah}

Kekurangan pasokan gas lembam ke dalam tangki di atas kapal pada waktu kapal melakukan proses bongkar muat dapat mengganggu keselamatan kapal karena kebutuhan gas lembam sangat penting untuk mencegah kebakaran dalam penganganan muatan maka sistem pesawat gas lembam sebagai alat yang dapat memproduksi gas lembam harus berkerja secara optimal. Segala upaya untuk meningkatkan perawatan harus dilakukan dengan cara yang seksama 
agar sistem gas lembam dapat bekerja dengan baik. Sering kali pada suatu penanganan muatan sistem gas lembam tidak beroperasi sesuai yang diharapkan, yaitu jumlah gas lembam yang masuk ke dalam tangki muatan yang tidak optimal dan sering terjadi alarm low pressure. Adapun masalahmasalah yang menyebabkan pasokan gas lembam tidak maksimal yang akan dibahas oleh peneliti adalah:

1. Faktor apa saja yang menyebabkan kurangnya supply gas lembam ke dalam tangki muatan?

2. Hal-hal apa saja yang dapat terjadi apabila supply gas lembam di dalam tangki kurang pada saat penanganan muatan?

3. Upaya apa saja yang harus dilakukan untuk menjaga optimalnya kinerja sistem gas lembam tersebut?

Dari hasil analisa yang ada pada diagram fishbone peneliti akan memperjelas dengan menggunakan tabel, di mana isi dalam tabel hanya mengambil secara garis besar sebab akibat dari permasalahan pada rumusan masalah yang dianalisa melalui diagram fishbone.

Tabel 2. Garis Besar Isi Permasalahan Dalam Diagram Fishbone

\begin{tabular}{|c|c|}
\hline Faktor yang diamati & Masalah yang terjadi \\
\hline 1. Man & $\begin{array}{l}\text { a. Kurangnya pengetahuan } \\
\text { tentang inert gas system. } \\
\text { b. Kurangnya pemahaman } \\
\text { perawatan inert gas system. }\end{array}$ \\
\hline 2. Method & $\begin{array}{l}\text { a. Tidak datangnya spare part } \\
\text { meskipun sudah di order. } \\
\text { b. Kurangnya pelatihan dari } \\
\text { perusahaan. }\end{array}$ \\
\hline 3. Material & $\begin{array}{l}\text { a. Rusaknya saringan } \\
\text { scrubber. } \\
\text { b. Rusaknya saringan deck } \\
\text { water seal. }\end{array}$ \\
\hline 4. Machine & $\begin{array}{ll}\text { a. } & \text { Saluran instalasi pipa } \\
\text { tersumbat. } \\
\text { b. Supply gas lembam tidak } \\
\text { optimal. }\end{array}$ \\
\hline
\end{tabular}

\section{Pembahasan Masalah}

1. Faktor yang menyebabkan kurangnya supply gas lembam ke dalam tangki muatan.

Berdasarkan permasalahan yang terjadi, maka Masinis melakukan pengecekan terhadap penyebab timbulnya masalah. Setelah melakukan beberapa analisa ditemukan adanya faktor, yang diduga sebagai penyebab timbulnya masalah, yaitu:

a. Adanya alarm pada engine control room yang yang menunjukkan bahwa alarm low pressure pada tangki muatan sehingga konsentrasi oxygen gas lembam pada tangki muatan cukup tinggi.

b. Kurangnya perawatan dan pemeliharaan yang harus dilakukan terhadap komponen-komponen yang terdapat pada gas lembam.

2. Hal-hal yang dapat terjadi apabila supply gas lembam di dalam tangki kurang pada saat penanganan muatan.

Karena kadar prosentase oxygen $\left(\mathrm{O}_{2}\right)$ di dalam tangki muatan pada waktu bongkar muat (cargo operation) berada di atas dari keadaan normal yaitu lebih besar dari $8 \%$ bisa mengakibatkan gangguan keselamatan bagi crew atau ABK di atas kapal tanker. Dari tingginya kadar $\mathrm{O}_{2}$ maka bisa mendukung terjadinya bahaya kebakaran yang dengan seiring waktu yang lama juga bisa mengakibatkan peningkatan tekanan di dalam tangki muatan sehingga terjadi ledakan (explosive) pada tangki tersebut tidak dapat dihindari lagi.

Selain itu hasil reaksi kimia yang dihasilkan banyak yang 
mengandung racun bagi tubuh manusia, sehingga akan sangat berbahaya apabila gas hasil reaksi tersebut terhisap oleh para crew di kapal tanker khususnya, karena rata-rata gas hasil reaksi tersebut memiliki kadar racun yang sangat tinggi.

Bahaya keselamatan yang dapat terjadi apabila terjadi kegagalan fungsi dari inert gas system pada saat penanganan muatan/bongkar muat antara lain:

a. Kebakaran (fire)

b. Ledakan (explosion)

c. Keracunan gas (toxit)

3. Upaya yang harus dilakukan untuk menjaga optimalnya kinerja sistem gas lembam tersebut.

Ada beberapa komponen utama yang perlu secara rutin diperiksa dan diperhatikan, seperti tersebut di bawah ini:

a. Inert gas scrubber

Pemeriksaan dilakukan melalui lubang orang (manhole) dan yang perlu diperhatikan adalah bagianbagian yang terkena karat, kotoran-kotoran dan bagianbagian yang rusak.

b. Inert gas blower

1) Pemeriksaan bagian dalam secara visual setiap saat akan dapat membantu mengetahui kerusakan sedini mungkin. Monitoring dengan sistem diagnosa harus digunakan karena dengan cara ini sangat membantu untuk memelihara kemampuan yang efektif dari peralatan ini. Dengan memasang dua gas blower yang sama ukuran dan kapasitasnya, memungkinkan penggunaan spare parts lebih flexible. Dengan demikian juga bisa disuplai satu spare impeller dan shaft yang bisa sewaktuwaktu digunakan untuk mengganti yang rusak pada salah satu blower.

2) Pemeriksaan secara visual melalui lubang-lubang yang tersedia pada tutup blower cukup untuk mengetahui keadaan dari bagian-bagian lain dalam blower.

\section{c. Deck Water Seal}

Pemeriksaan pada deck water seal harus meliputi bagian dalam yang membutuhkan mengenai:

1) Venturi lines pada type dry dari water seal;

2) Karat-karat yang mungkin timbul pada pipa air masuk dan housing;

3) Karat-karat yang mungkin ada pada heating coils, heating coil dipasang pada kapal-kapal yang berlayar di daerah dingin;

4) Karat-karat atau endapanendapan yang mungkin ada pada drain dari air, supply valves dan level monitoring;

5) Harus ditest apakah tetap berfungsi dengan baik.

d. Non Return Valve Non return valve harus sering-sering dibuka dan diperiksa jangan sampai berkarat dan dudukan valve (valve seat) harus diperiksa. Valve ini harus diperiksa apakah bisa berfungsi selama inert gas system (IGS) dioperasikan. 
e. Scrubber effluent line (sistem pembuangan dari scrubber)

Alat ini hanya dapat diperiksa kalau kapal di atas dock. Overboard discharge valve dan pipa yang langsung melekat pada sisi kapal dan valve tersebut (side stub piece) harus diperiksa setiap kapal naik dock.

f. Pemeriksaan pada instalasi pipa

Pemeriksaan pada pipa instalasi inert gas juga berpengaruh besar pada pengoperasian sistem gas lembam. Seiring dengan lamanya usia kerja sebuah sistem, tidak menutup kemungkinan saluran pipa sistem gas lembam terhambat oleh jelaga yang menempel di dinding lubang pipa yang lama kelamaan membuat lubang pipa semakin kecil, dan mengakibatkan aliran gas lembam terhambat. Oleh karena itu pemeriksaan secara berkala pada sistem pipa gas lembam sangat perlu dilakukan.

\section{PENUTUP}

Sebagai bagian akhir dari penelitian ini penulis memberikan kesimpulan dan saran yang berkaitan dengan masalah yang dibahas dalam penelitian ini, yaitu:

\section{a. Kesimpulan}

Dari keseluruhan uraian-uraian tersebut di atas diperoleh beberapa kesimpulan menurut hasil pengamatan dan analisa yang telah dilakukan selama ini. Penyebab dari kebakaran dan ledakan yang merupakan bahaya terbesar bagi gangguan keselamatan yang dapat terjadi pada kapal-kapal tanker adalah disebabkan adanya tiga unsur kebakaran yaitu: Source of ignition (sumber penyalaan) Fuel (bahan bakar/material) Oxygen yang cukup

Dimana dari ke-3 unsur tersebut dapat ditekan kadarnya dari volume. Dalam hal ini adalah oxygen, dengan menggunakan sistem gas lembam/inert gas yang berasal dari hasil pembakaran dalam scrubber, yang mana gas yang dikeluarkan tersebut dapat digunakan apabila kandungan oxygen-nya memenuhi persyaratan (kurang dari 8\%). Untuk itu dari hasil analisa data maka dapat disimpulkan:

1. Perawatan inert gas (gas lembam) pada penanganan muatan di MT. Gandini, belum mencapai hasil yang maksimal dikarenakan oleh tersumbatnya saluran pipa instalasi gas lembam yang mengakibatkan supply gas lembam menuju tangki muatan menjadi terhambat dan kurangnya perawatan dan pemeliharaan terhadap penanganan instalasi gas lembam beserta komponen-komponen penunjang mengakibatkan masih tingginya kadar oxygen di dalam sistem gas lembam di kapal.

2. Kegagalan fungsi dari inert gas system adalah kebakaran (fire), ledakan (explosion), dan keracunan gas (toxit).

3. Untuk menurunkan kadar oksigen $\left(\mathrm{O}_{2}\right)$ pada IGS adalah dengan memaksimalkan perawatan setiap tiga kali proses bongkar muat kapal dan selalu memonitor keadaan inert gas system.

\section{b. Saran}

Kapal tanker terutama yang berbobot mati 20.000 dwt ke atas perlu dilengkapi dengan IGS, agar tidak terjadi resiko kebakaran dan ledakan yang dapat menimbulkan korban berupa materi, muatan dan 
Pengaruh Kurangnya Supply Gas Lembam Dalam Penanganan Muatan Di Mt. Gandini Dengan Metode Fishbone

Sarifuddina, Winarno $^{\mathrm{b}}$ dan Jijin Arga Saputra ${ }^{\mathrm{c}}$

pencemaran serta jiwa manusia.

1. Agar proses pelaksanaan perawatan terhadap sistem pipa instalasi gas lembam dilakukan dengan membuat Plan Maintenance Schedule, sehingga supply gas lembam ke dalam tangki muatan tidak terhambat.

2. Agar memasang ramburambu/tanda keselamatan dan peringatan pada tempat-tempat yang berbahaya dan menjaga gas lembam pada kondisi yang normal.

3. Agar melakukan perawatan dan pemeliharaan secara detail pada sistem inert gas dan mengganti saringan demister yang rusak.

\section{DAFTAR PUSTAKA}

Fathoni, Abdurrahmat. 2006. Metodologi Penelitian \& Teknik Penyusunan Skripsi. Jakarta : PT Rineka Cipta

Pieter, Batti. 2000. Inert Gas System dan Crude Oil Washing. Semarang : Politeknik Ilmu Pelayaran Semarang

Badan Diklat Perhubungan. Oil Tanker Familirization. Tanker Familiarization Course (TFC). Modul -1 (Cetakan Pertama Maret
2000) Dephub

Badan Diklat Perhubungan. Oil Tanker Familirization. Tanker Familiarization Course (TFC). Modul -3 (Cetakan Pertama Maret 2000) Dephub

Hunt, Everett C. 2002. Modern Marine Engineers's Manual Volume II, Third Edition. Centreville, Maryland : Cornell Maritime Press

Patilima, Hamid. 2013. Metode Penelitian Kualitatif. Bandung : Alfabeta

Kashiwa-Peabody Marine. Inert Gas System. (Instruction Book MT. GANDINII / PNGS)

Anggoro, M. Toha. 2012. Metode Penelitian. Jakarta : Universitas Terbuka

Sugiyono. 2013. Metode Penelitian Pendidikan. Pendekatan Kuantitatif, Kualitatif, dan $R \& D$. Bandung : Alfabeta

Wright A. A. 2000. Exhaust Emissions from Combustion Machinery. BP Marin 